\title{
Assessment of the Proximate and Elemental Composition of the Leaves, Stem Bark and Roots of Bobgunnia fistuloides
}

\author{
Samuel Egwu Anwani", Muhammed Binin Etsuyankpa, Sule Philip Ivoms Ogah \\ Department of Chemistry, Federal University of Lafia, Lafia, Nigeria \\ Email address: \\ anwanisamuel@gmail.com (S. E. Anwani) \\ ${ }^{*}$ Corresponding author
}

\section{To cite this article:}

Samuel Egwu Anwani, Muhammed Binin Etsuyankpa, Sule Philip Ivoms Ogah. Assessment of the Proximate and Elemental Composition of the Leaves, Stem Bark and Roots of Bobgunnia fistuloides. World Journal of Applied Chemistry. Vol. 5, No. 4, 2020, pp. 57-64.

doi: $10.11648 /$ j.wjac.20200504.11

Received: October 23, 2020; Accepted: November 5, 2020; Published: November 16, 2020

\begin{abstract}
Bobgunnia fistuloides is a leguminous plant which belong to the family of fabaceae. Ethno-medicinally, Bobgunnia fistuloides parts (leaves, bark and roots) have been used by the Nupe communities, Niger State, Nigeria to treat various diseases for decades. This research assessed the proximate composition and elemental composition of the leaves, stem bark and roots of Bobgunnia fistuloides. The $\mathrm{Ca}, \mathrm{Mg}$ and $\mathrm{Fe}$ content in the plant parts were investigated using atomic absorption spectrophotometer while as the $\mathrm{Na}$ and $\mathrm{K}$ content were assessed using flame photometer. More so, the proximate compositions of the leaves, stem bark and roots were analyzed using standard methods. The results of the proximate analysis, in percentages, revealed the values of $10.01 \pm 0.15,9.40 \pm 0.46,10.61 \pm 0.18 ; 32.40 \pm 0.16,36.20 \pm 2.47,33.00 \pm 0.20 ; 2.71 \pm 0.16,10.13 \pm 0.26$, $11.27 \pm 0.08 ; 3.28 \pm 0.22,2.91 \pm 0.13,3.50 \pm 0.44 ; 0.88 \pm 0.01,1.06 \pm 0.02,1.08 \pm 0.02$ and $50.73 \pm 2.51,40.30 \pm 1.87,40.25 \pm 1.09$ respectively for the moisture, ash, crude fibre, crude protein, crude fat and crude carbohydrates contents of leaves, stem bark and roots of the plant. On the other hand, the nutritive values in $\mathrm{mg} / \mathrm{kg}$ were: $\mathrm{K}(822.20 \pm 0.20,756.13 \pm 0.06,652.67 \pm 3.05)$; $\mathrm{Na}$ (507.24 $\pm 0.08,496.13 \pm 0.06$ and $252.83 \pm 0.04), \mathrm{Ca}(2405.48 \pm 0.43,1208.64 \pm 0.02$ and $977.36 \pm 0.57), \mathrm{Fe}(102.07 \pm 0.05$, $70.44 \pm 0.04$ and $6.17 \pm 0.31), \mathrm{Mg}(580.20 \pm 0.07,448.54 \pm 0.29$ and $206.35 \pm 0.25)$ respectively for the leaves, stem bark and roots of this plant. These results indicate that the roots of Bobgunnia fistuloides contain relatively lowest amounts of the elements determined followed by the stem bark while the leaves have the highest. These results also reveal that the carbohydrates, calcium and potassium contents of the leaves were the highest compared to those of the other parts analyzed. The results also reveal that since such parameters including the ash contents among other parameters investigated were high, all the parts of this plant could serve as good sources of nutrients when properly utilized.
\end{abstract}

Keywords: Bobgunnia fistuloides, Proximate Composition, Analysis and Nutrients

\section{Introduction}

\subsection{Importance of Proximate Composition}

The proximate compositions of materials including plants and animals which are the ash, moisture, fibre, fat, protein and carbohydrates are of great importance in nutrition especially in feed formulations. The carbohydrate contents in plants contribute to their physiological functions serving as the major source of energy. Proteins help to boost the immune system, repair worn out tissues, involved in the production of enzymes and contribute to cell divisions [1]. On the other hands, fats help to regulate blood pressure in humans and promote the repair of vital cells. They also serve as thermal insulators. The moisture content in plants dissolves essential nutrients and carries the nutrients to all parts of the plant thereby promoting efficient functions of the organs [2]. The ash content of plants refers to the amount of the mineral elements present, which helps in maintaining the acid-alkaline balance of the blood system in animals which consume the plants [3]. Fibres are 
parts of fruits, grains and vegetables which can neither be digested nor absorbed by the human system. Dietary fibres reduce gastrointestinal problems such as diarrhoea and prevent colon cancer and cardiovascular diseases [1].

\subsection{Plant Description}

Bobgunnia are of two different species; Bobgunnia fistuloides (Harms) and Bobgunnia madagascariensis. These two species have a chromosome number of $2 n=16$. Where $n$ is the number of haploid. Bobgunnia fistuloides called Paorosa in English is a leguminous plant belonging to the family of leguminosae-fabaceae. It is a flowering plant that belongs to the subfamily faboideae. The plant has been reported to be found in Nigeria, particularly in some parts of Niger State in Nigeria, Côte d'Ivoire, Ghana and Cameroon [4]. In Nigeria, the Nupe tribe in Niger State knows Bobgunnia fistuloides as Gbogi while the Hausas call it Dufai or Farau. Bobgunnia fistuloides is a tree that grows very tall in a rainforest and semi-deciduous forest, up to 500 $\mathrm{m}$ tall [5]. It has flowers in groups of 1-4. It undergoes bisexual reproduction thus, a sweet scented plant. The bark surface is slightly fissured, having watery exudates. The seed is kidney-shaped with grayish appearance. It undergoes epigeal germination and it has alternate leaves [4]. The leaves and the pods of this plant can be used as compost manure since they are a rich source of nitrogen [5].

\subsection{Uses of Bobgunnia Fistuloides}

Bobgunnia fistuloides is used traditionally for house posts, mortars, pestles, flooring, decorative items, turnings, furniture, small carvings, agricultural implements, tool handles and it is a good source of firewood [4]. Traditionally, the Nupe people of Northern Nigeria use the bark decoction of this plant for the stimulation of milk in nursing mothers, treatment of diseases such as fever, diarrhoea, gonorrhoea, menstrual problems, skin diseases and filariasis of the eye [4]. The service life and natural durability of Bobgunnia madagascariensis (another species of Bobgunnia fistuloides) to termite attack were investigated by Ncube et al., [30]. The analyses revealed that Bobgunnia madagascariensis showed a high resistance on short duration field exposure to subterranean termites (Coptotermes formosanus) and was highly durable. This could be attributed to the low moisture content in this species of Bobgunnia. Several analysis have been carried out on the other species of the Bobgunnia (B. madagascariensis). This research analyzed the proximate composition and elemental constituents of the leaves, stem bark and roots of Bobgunnia fistuloides.

\section{Materials and Methods}

\subsection{Plant Collection, Identification and Preparation}

The leaves, roots and stem bark of Bobgunnia fistuloides were collected at Binin village in Gbako Local Government area, Niger State, Nigeria. It was identified at the herbarium section of the Department of Botany, Federal University of
Lafia, Nasarawa State, Nigeria. The materials collected were shade dried in an open air and crushed into powder using a milling machine [6].

\subsection{Sample Preparation (Digestion of Sample)}

Half gram of the crushed sample each of leaves, roots and stem bark was measured using electronic weighing balance (FA1004 N), transferred into three different crucibles. The samples were ashed for 3 hours in Muffle furnace (TMAX-1750DD). Thirty millilitres of aqua regia were added into the ashed samples and were centrifuged for 15 minutes. The obtained digests were transferred quantitatively into $50 \mathrm{~mL}$ volumetric flasks and made up to the marks.

\subsection{Mineral Analysis}

\subsubsection{Determination of Calcium, Magnesium and Iron}

Appropriate dilutions were made for each elemental determination from the digested samples. Stock solutions containing the elements of interest were prepared. Appropriate lamps and suitable wavelengths for the elements $(\mathrm{Ca}, \mathrm{Mg}$ and $\mathrm{Fe}$ ) were accurately selected. The mineral analysis was carried out using atomic absorption spectrophotometer (Bulk 550) and the concentration values were recorded according to the method described by Okalebo et al., [7].

\subsubsection{Determination of Sodium and Potassium Using Flame Photometry}

From the digested samples, aliquot portions were aspirated into flame photometer using flame analyzer (FP8600). Suitable wavelengths for sodium $(767 \mathrm{~nm})$ and potassium $(589 \mathrm{~nm})$ were selected. Sodium and potassium concentrations were obtained from the calibration curves of the standards according to the methods described by Onwuka [8].

\subsection{Proximate Analysis}

The methods described in AOAC [9] were used to analyze the proximate composition (moisture, ash, fibre, fat and protein) of the plant parts selected for this study, while the carbohydrate contents were determined by subtracting the sum of the values of the other nutrients from 100 .

\subsubsection{Determination of Moisture Content Using Oven Drying Method}

The oven drying method of AOAC [9] (method 930.15) was used. Four grams each of the plant samples was weighed into a previously weighed platinum crucibles using analytical balance (SKZ-A1004). The crucibles containing the plant samples were weighed. The samples were dried in an oven (DHG-9101. SA) at $105^{\circ} \mathrm{C}$ for 3 hours until constant weights were obtained. They were cooled in a desiccator and re-weighed. The samples were subjected to drying in the oven to obtain constant weights at $95-100^{\circ} \mathrm{C}$ under pressure not exceeding $100 \mathrm{mmHg}$. Drying and weighing continued until constant weights were obtained. The weights of moisture lost were calculated and expressed as percentages of the weights of the samples analyzed. The formula below was used to 
express the moisture contents:

$$
\text { Moisture content }(\%)=\frac{W_{2}-W_{3}}{W_{2}-W_{1}} \times 100
$$

$\mathrm{W}_{1}=$ Weight of empty crucible

$\mathrm{W}_{2}=$ Weight of crucible + Sample before drying

$\mathrm{W}_{3}=$ Weight of crucible + Sample dried to a constant weight

\subsubsection{Determination of Protein}

The crude proteins of the samples were determined using the Kjeldahl method as described by AOAC, [9] (Method No. 978.04). The total nitrogen was determined and multiplied by a nitrogen-to-protein conversion factor (6.25) to obtain the percentage protein content.

\subsubsection{Digestion of Sample}

Half gram of each plant sample was mixed with $10 \mathrm{~cm}^{3}$ of concentrated $\mathrm{H}_{2} \mathrm{SO}_{4}$ in a digestion (Kjeldahl) flask. This was followed by the addition of $0.4 \mathrm{~g}$ of copper sulphate $\left(\mathrm{CuSO}_{4}\right)$ and $3.5 \mathrm{~g}$ of $\mathrm{K}_{2} \mathrm{SO}_{4}$ before heating under a fume cupboard with occasional shaking till the solution assumed a green colour (at a temperature of $460^{\circ} \mathrm{C}$ for 30 minutes). The black particles that appeared at the mouth and neck of the flask were washed with distilled water into the flask. The sample was re-heated gently at first until the green colour disappeared (the digest). Then, the digest was allowed to cool. The digest was transferred into a $100 \mathrm{~cm}^{3}$ volumetric flask and then distilled water was added to make up to the mark.

\subsubsection{Protein Distillation Procedure}

The Markham distillation apparatus was steamed for 15 minutes. $100 \mathrm{~mL}$ conical flask containing $5 \mathrm{~cm}^{3}$ of $2 \%$ boric acid indicator containing 3 drops of mixed indicator (bromocressol green/methyl red) was placed under the condenser.

Five mililitres of the digest was transferred into the body of the apparatus via the small funnel aperture, followed by the addition of $40 \% \mathrm{NaOH}\left(10 \mathrm{~cm}^{3}\right)$ solution in the distillation apparatus. The mixture was allowed to steam for 5-7 minutes to collect enough ammonium sulphate. The ammonia that was generated was collected in an excess of boric acid which yielded ammonium borate.

\subsubsection{Titration}

The distillate (ammonium borate) in the receiving flask was titrated against $0.1 \mathrm{M}$ hydrochloric acid (at end point, the colour changed from green to a deep red). The nitrogen content and hence the protein content was calculated using the formula below:

$$
\text { Protein }(\%)=\mathrm{N}_{2}(\%) \times 6.25
$$

The percentage nitrogen content was calculated using the formula below:

$$
\% \mathrm{~N}=\frac{M \times 0.0014 \times V_{t} \times T}{W}
$$

$\mathrm{W}=$ Weight of sample $(1.00 \mathrm{~g})$

$\mathrm{M}=$ Concentration of the titrant $\left(0.1 \mathrm{moldm}^{-3} \mathrm{HCl}\right)$

$\mathrm{V}_{\mathrm{t}}=$ Total volume of distillate $\left(50 \mathrm{~cm}^{3}\right)$

\section{$\mathrm{T}=$ Titre value obtained}

\subsubsection{Determination of Total Ash Content}

The ash content was determined using furnace incineration gravimetric method described by Onwuka [8]. A $2.00 \mathrm{~g}$ of each finely grounded sample was weighed in triplicate and transferred into previously weighed crucibles. The samples were burnt to ashes in a muffle furnace (TMAX-1750DD) at $550^{\circ} \mathrm{C}$ for 2 hours until a whitish-grey ashes were formed. After ashing, the crucibles were placed in a desiccator to cool and re-weighed. The weight losses were reported as the ash using the formula below:

$$
\operatorname{Ash}(\%)=\frac{W_{2}-W_{1}}{\text { Weight of sample }} \times 100
$$

Where

$\mathrm{W}_{1}=$ Weight of crucible

$\mathrm{W}_{2}=$ weight of crucible + ash

\subsubsection{Determination of Crude Fibre}

Crude fibre were determined using the method described by Onwuka [8]. Two grams of the powdered sample was boiled in triplicate in $200 \mathrm{~cm}^{3}$ solution of $1.25 \% \mathrm{H}_{2} \mathrm{SO}_{4}$ for 30 minutes under reflux. The boiled samples were washed in several portions of hot water using a two-fold cloth to trap the particles until no more acid present in the washings. The residues were transferred into $250 \mathrm{~cm}^{3}$ beakers and boiled for 30 minutes with $200 \mathrm{~cm}^{3}$ of the solution containing $1.25 \mathrm{~g}$ $\mathrm{NaOH}$. After washing in several portions of hot water, the samples were allowed to drain before being transferred quantitatively to weighed crucibles where they were dried in the oven at $105^{\circ} \mathrm{C}$ to obtained constant weights. The crucibles were ignited in the muffle furnace (TMAX-1750DD) $\left(400-600^{\circ} \mathrm{C}\right)$ and ashed for 4 hours. The crucibles were placed in a desiccator to cool and afterwards, re-weighed. The loss in weight after incineration is the fibre content.

$\%$ Crude fibre $=$ Loss in weight after incineration $\times 100$

\subsubsection{Assessment of Crude Fat}

This was determined using Soxhlet extraction method as described by Onwuka [8]. A $2.00 \mathrm{~g}$ of the plant sample was weighed in triplicate into thimbles. The thimbles containing the plant samples were placed in a Soxhlet reflux flask and mounted into a weighted extraction flask. The boiling flask was filled with $300 \mathrm{~cm}^{3}$ of petroleum ether (boiling point $\left.40-60^{\circ} \mathrm{C}\right)$. The Soxhlet apparatus was assembled and allowed to reflux for 6 hours. The flask with the fat was disconnected and placed in an oven at $105-110^{\circ} \mathrm{C}$ for 1 hour. The flask was placed in a desiccator and was allowed to cool before it was weighed.

The weight of oil (fat) extract was determined by subtracting the weight of the flask and the percentage of the fat content was calculated using the formula below:

$$
\text { Fat }(\%)=\frac{W_{2}-W_{1}}{\text { Weight of sample }} \times 100
$$

Where:

$\mathrm{W}_{2}=$ Weight of empty extraction flask + oil $\mathrm{W}_{1}=$ Weight of empty extraction flask 


\subsubsection{Carbohydrate Content and Caloric Value Determination}

The carbohydrate contents $(\%)$ of the samples were calculated by weight difference method [100- (ash + moisture + fat + fibre)] [8]. The caloric value was calculated from the sum of the percentages of proteins, carbohydrates and total lipids multiplied by the energy per gram factors 4, 4 and 9 (kcal/g) respectively [8].

\subsection{Statistical Analysis}

All the determinations were carried out in triplicates and the data obtained were expressed as mean \pm standard deviations. All data were analyzed using Statistical Package for the Social Sciences (SPSS 25.0). The results were expressed using one way ANOVA and Duncan's multiple to compare the significant differences at $\mathrm{p}<0.05$ [14].

\section{Results and Discussion}

\subsection{Results}

Table 1. Percentage (\%) Proximate Composition of the Leaves, Root and Stem Bark of Bobgunnia fistuloides and their Caloric Values ( $\mathrm{kCal} / 100 \mathrm{~g}$ ).

\begin{tabular}{llll}
\hline Parameters & Leaves & Roots & Stem bark \\
\hline Moisture content & $10.01 \pm 0.15^{\mathrm{b}}$ & $10.61 \pm 0.18^{\mathrm{c}}$ & $9.40 \pm 0.46^{\mathrm{a}}$ \\
Ash content & $32.40 \pm 2.16^{\mathrm{a}}$ & $33.00 \pm 0.20^{\mathrm{b}}$ & $36.20 \pm 2.47^{\mathrm{c}}$ \\
Crude fibre & $2.71 \pm 0.16^{\mathrm{a}}$ & $11.27 \pm 0.08^{\mathrm{c}}$ & $10.13 \pm 0.26^{\mathrm{b}}$ \\
Crude protein & $3.28 \pm 0.22^{\mathrm{b}}$ & $3.50 \pm 0.44^{\mathrm{c}}$ & $2.91 \pm 0.13^{\mathrm{a}}$ \\
Crude fat & $0.88 \pm 0.01^{\mathrm{a}}$ & $1.08 \pm 0.02^{\mathrm{b}}$ & $1.06 \pm 0.02^{\mathrm{c}}$ \\
Carbohydrate & $50.73 \pm 2.51^{\mathrm{c}}$ & $40.25 \pm 1.09^{\mathrm{b}}$ & $40.30 \pm 1.87^{\mathrm{a}}$ \\
Caloric value & $223.99 \pm 9.75^{\mathrm{c}}$ & $184.70 \pm 2.75^{\mathrm{b}}$ & $182.35 \pm 8.02^{\mathrm{a}}$ \\
\hline
\end{tabular}

Values are mean $\pm \mathrm{SD}$ of triplicate determinations. Figures with the same superscript along the same row are significantly different at $\mathrm{p}<0.05$.

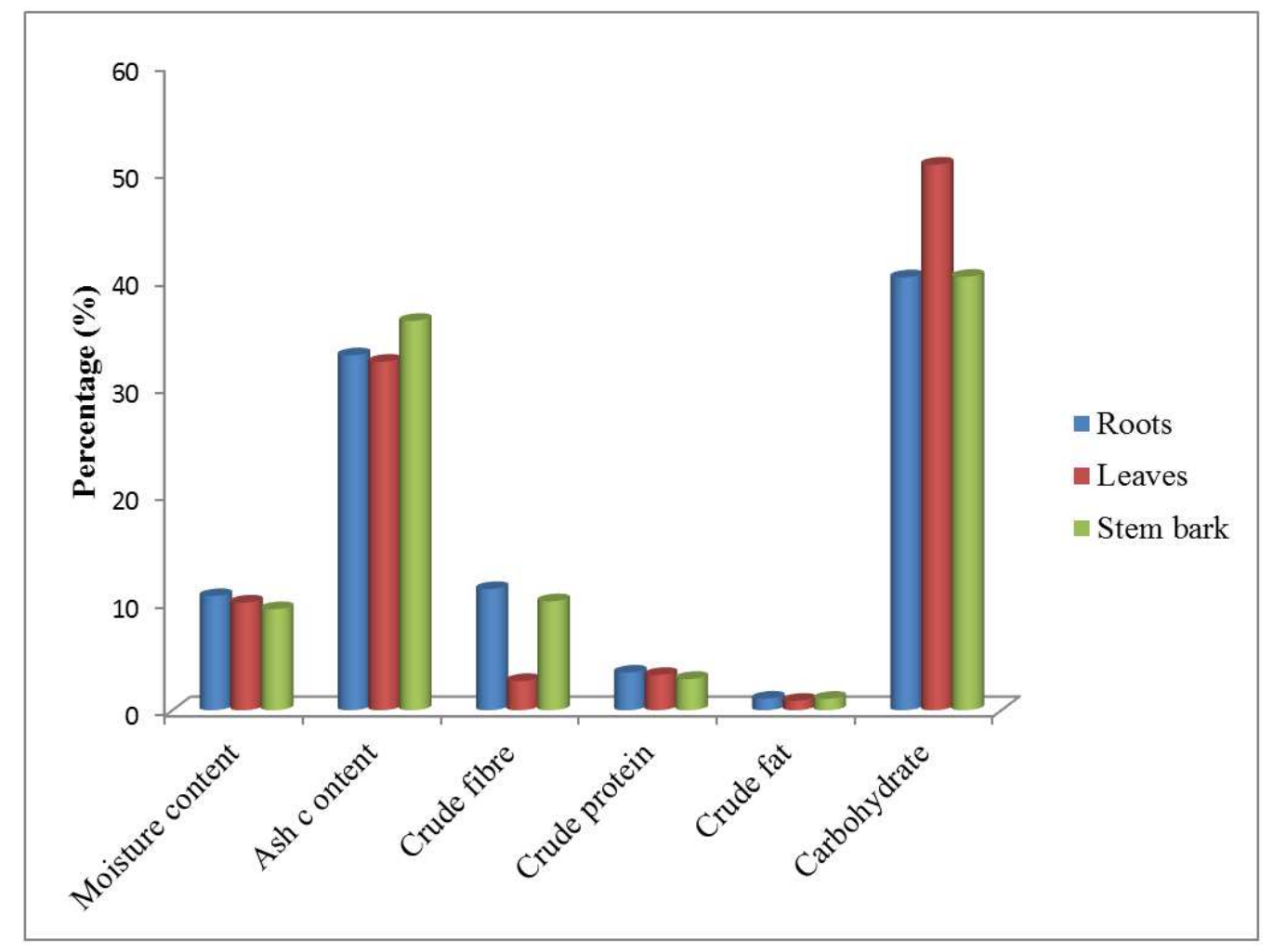

Figure 1. Percentage (\%) proximate composition of the roots, leaves and stem bark of Bobgunnia fistuloides.

\subsection{Discussions}

\subsubsection{Proximate Composition}

Table 1 shows the results of the proximate composition of the leaves, roots and stem bark of Bobgunnia fistuloides. The moisture content of the root $(10.61 \pm 0.18)$ had a significant $(\mathrm{p}<0.05)$ increase when compared to values obtained in the leaves $(10.01 \pm 0.15)$ and stem bark $(9.40 \pm 0.46)$. The moisture content in $B$. fistuloides were above the values reported by Keta et al., [6] on some medicinal plants such as Senna obtusifolia (8.5\%), Cleome gynandra (7.0\%) and Leptadenia hastate (5.5\%). According to Keta et al., [6] reported that moisture content above $15 \%$, the value above which promotes microbial growth. This indicates that $B$. fistuloides parts will have long life shelf, low degree of fungal and bacterial attack.

Furthermore, Table 1, shows that the ash content of the leaves $(32.40 \pm 2.16 \%)$ is lower compared to that of the root $(33.00 \pm 0.20 \%)$ and the stem bark $(36.20 \pm 2.47 \%)$. The stem bark had more ash content than the leaves and the roots, showing that it contains more mineral deposits than the other parts of the plant. Ash content in all the parts were relatively higher compared to the other leafy plants such as Talinum triangulare $(20.05 \%)$, Occimum graticimum (8.0\%) and Hibiscus esculentus $(8.00 \%)$ analyzed by Akindahunsi and Salawu [10]. The ash contents of B. fistuloides parts indicate high contents of mineral elements in this plant [8].

More so, Table 1, indicates that the crude fibre content of the roots $(11.27 \pm 0.08 \%)$ is higher than that of the stem bark 
$(10.13 \pm 0.26 \%)$ as well as the leaves $(2.71 \pm 0.16 \%)$. The fibre contents of the leaves of $B$. fistuloides parts is similar with the values reported by Olayiwola [11], on some medicinal plants such as Mimosa pudica (3.30\%), Persia Americana (2.87\%) and Bambusa vulgaris (3.57\%). According to Ayoola and Adeyeye [12], reported that crude fibre reduces the chances of diarrhoea by increasing the weight and size of stool. It can also lower the risk of coronary diseases, serum cholesterol level, hypertension, constipation, diabetes and breast cancer [13]. The result obtained for the crude fibre content is an indication that if $B$. fistuloides parts (extracts) are taken, it can possibly also remedy the aforementioned diseases.

The crude protein content of the root was found to be $3.50 \pm 0.44 \%$ which was relatively higher than that of the leaves $(3.28 \pm 0.22 \%)$ and the stem bark $(2.91 \pm 0.13 \%)$. The crude protein content reported in this study is lower compared to the protein content in Newbouldia leavis $(5.68 \%)$ and Allium satium (4.63\%) as stated by Ayoola et al., [14]. These values show that the protein contents, on the other hand, of these plant parts are low. This shows that the plant parts cannot be potential sources of proteins. However, it is envisaged that the adequate intake of the plant extracts of these plant parts can add to the formation of hormones, production of enzymes, boost the immune system and repair warn out tissues [1].

The values (in percentages) obtained for the crude fat in the leaves, root and stem bark were $0.88 \pm 0.01,1.08 \pm 0.02$, $1.06 \pm 0.02$ respectively. The crude fat contents of all the parts are low compared to those of leaves of Cajanus cajan $(2.72 \%)$, Amaranthus hybridus (4.80\%) and Ipomoea batatas (4.90\%) as reported by David [15]. The recommended daily allowance
(RDA) of fat for adults should be $<30 \mathrm{kCal}$ per day as stated by WHO [16] and Hooper et al.,[17]. From the result, daily intake of the crude extract of the leaves, roots and stem bark of B. fistuloides parts can provide 7.37, 9.04 and $8.87 \mathrm{kCal}$ respectively per day. Antia et al., [18] reported that 1-2\% of fat content in any diet is enough to provide adequate caloric energy needed by the body system as excessive intake of fat can contribute to cardiovascular diseases. The results obtained indicate that the fat contents in B. fistuloides is within (1-2\%) the acceptable limit.

The percentage carbohydrate contents obtained for the leaves, roots and stem bark were $50.73 \pm 2.51,40.25 \pm 1.09$ and $40.30 \pm 1.87$ respectively. The recommended dietary allowance (RDA) for children, adults, pregnant and lactating mothers are $130 \mathrm{~g}, 130 \mathrm{~g}, 175 \mathrm{~g}$ and $210 \mathrm{~g}$ respectively [19]. Since $1 \mathrm{~g}$ of carbohydrate gives $8.37 \mathrm{kCal}$, it implies that $100 \mathrm{~g}$ of the leaves, roots and stem bark of this plant provides 424.61, 336.89 and $337.31 \mathrm{kCal}$ of energy respectively. The carbohydrate content of the leaves obtained in this study was higher than those of the roots and stem bark, it indicates that the leaves of $B$. fistuloides contains higher carbohydrate compared to the leaves of Tribulus terresteris (46.79\%) reported by Gonmong [20]. but lower than the leaves of Senna obtusifolia (80.67), Cleome gynandra (64.12) and Leptadenia hastate (62.99) as stated by Keta et al., [6]. Plants rich in carbohydrate and low in protein $(<20 \%)$ are usually considered as good energy sources [21]. This indicates that the carbohydrate content in $B$. fistuloides parts are sufficient to provide the energy needed by the body system if the extracts are used ethno-medicinally.

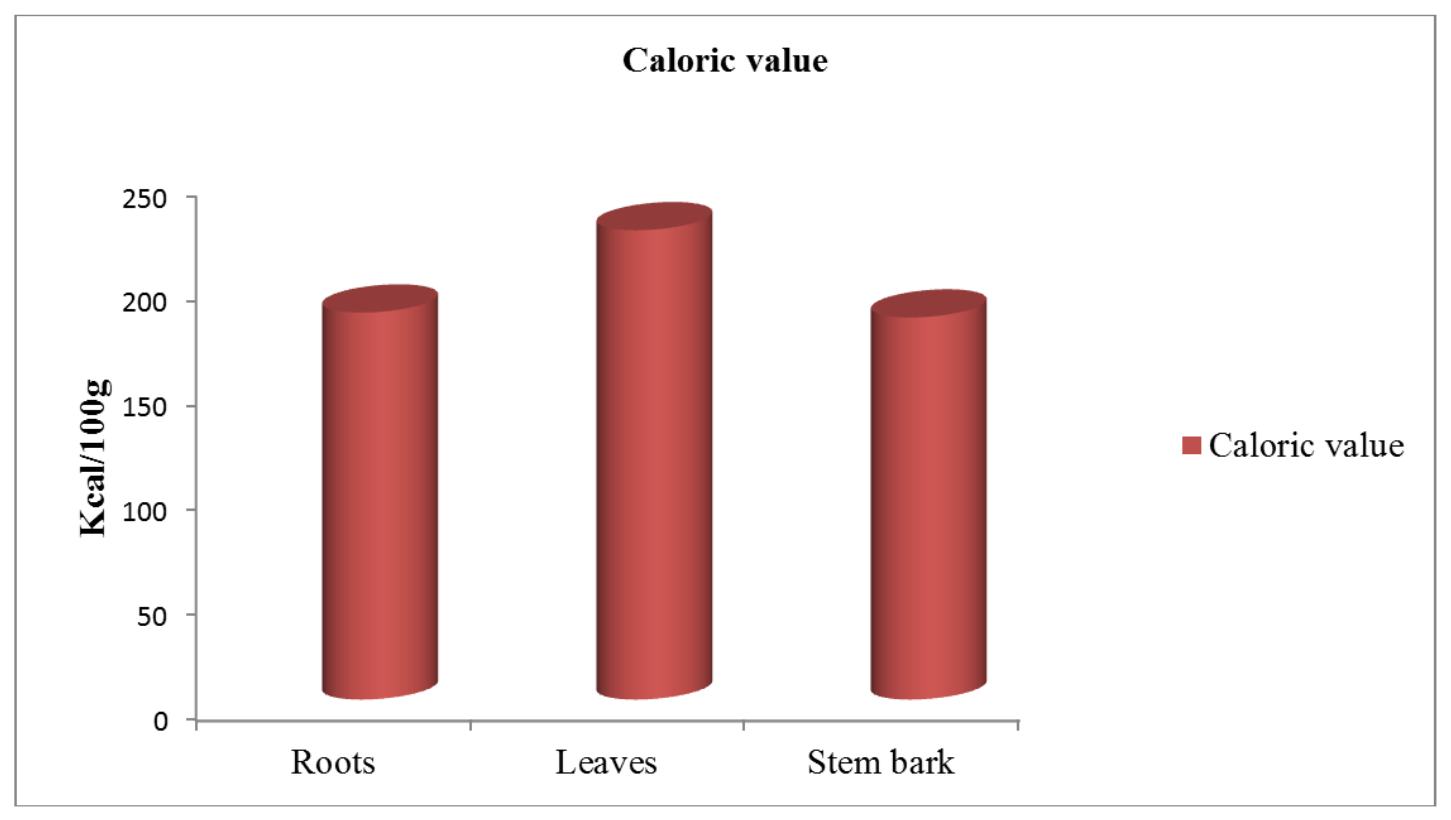

Figure 2. The caloric values of the leaves, stem bark and roots of Bobgunniafistuloides.

The result obtained for the caloric values indicate that the leaves contained higher caloric value $(223.99 \pm 9.75 \mathrm{kCal} / 100$ g) than the roots $(184.70 \pm 2.75 \mathrm{kCal} / 100 \mathrm{~g})$ and stem bark $(182.35 \pm 8.02 \mathrm{kCal} / 100 \mathrm{~g})$. However, all the parts have relatively high calorific values. Report show that if a plant contains high calorific value, it is nutritionally satisfactory and can provide the energy needed by the body. From the results obtained for the calorific value of $B$. fistuloides parts, it implies that an intake of the extracts (B. fistuloides) can as well provide satisfactory energy needed by the body. 


\subsubsection{Elemental Composition}

Table 2. Mineral Analysis of the Roots, Leaves and Stem bark of Bobgunnia fistuloides expressed in $\mathrm{mg} / \mathrm{kg}$.

\begin{tabular}{llll}
\hline \multirow{2}{*}{ Elements } & Plant Parts & & \\
\cline { 2 - 4 } & Roots & Leaves & Stem bark \\
\hline $\mathrm{K}$ & $652.67 \pm 3.05^{\mathrm{a}}$ & $822.20 \pm 0.20^{\mathrm{c}}$ & $756.13 \pm 0.06^{\mathrm{b}}$ \\
$\mathrm{Na}$ & $252.83 \pm 0.04^{\mathrm{a}}$ & $507.24 \pm 0.08^{\mathrm{c}}$ & $496.13 \pm 0.06^{\mathrm{b}}$ \\
$\mathrm{Ca}$ & $977.36 \pm 0.57^{\mathrm{a}}$ & $2405.48 \pm 0.43^{\mathrm{c}}$ & $1208.64 \pm 0.02^{\mathrm{b}}$ \\
$\mathrm{Fe}$ & $6.17 \pm 0.31^{\mathrm{a}}$ & $102.07 \pm 0.05^{\mathrm{c}}$ & $70.44 \pm 0.04^{\mathrm{b}}$ \\
$\mathrm{Mg}$ & $206.35 \pm 0.25^{\mathrm{a}}$ & $580.20 \pm 0.07^{\mathrm{c}}$ & $448.54 \pm 0.29^{\mathrm{b}}$ \\
\hline
\end{tabular}

Values are mean $\pm \mathrm{SD}$ of triplicate determinations. Figures with the same superscript along the same row are significantly different at $\mathrm{p}<0.05$.

The elemental analysis shown in Table 2 indicates the variations in the elemental compositions of the roots, leaves and stem bark of Bobgunnia fistuloides. The result of the analysis reveal that the leaves contained higher amount of potassium concentration $(822.20 \mathrm{mg} / \mathrm{kg})$ followed by the stem bark $(756.13 \mathrm{mg} / \mathrm{kg})$ while the lowest was in the roots $(652.67$ $\mathrm{mg} / \mathrm{kg})$.

The potassium content of $B$. fistuloides parts obtained in this study as shown in Table 2 are lower than those reported by Zain et al., [22], on some medicinal plants such as Alhagi maurorum (14991 mg/kg), Datura alba (13535 mg/kg), Chenopodium album $(10455 \mathrm{mg} / \mathrm{kg})$ and Tecomella undulate $(3840 \mathrm{mg} / \mathrm{kg})$. These differences in the concentrations of potassium in $B$. fistuloides parts and the plants reported by Zain et al., [22], could be attributed to the differences in ecological factors and the plant species. These values show that $B$. fistuloides parts is probably a poor contributor of potassium compared to the recommended daily intake of potassium (3500 $\mathrm{mg}$ per day) for humans as reported by Mart'inez-Ballesta et al., [23]. Reports show that K can help to maintain healthy blood pressure, enhance fertility and promote efficient function of the muscle and nerves [24]. Hence, B. fistuloides parts could be recommended as a veritable source of $\mathrm{K}$ and as such can help to maintain blood pressure, improve fertility, building up of myocyte and nerves.

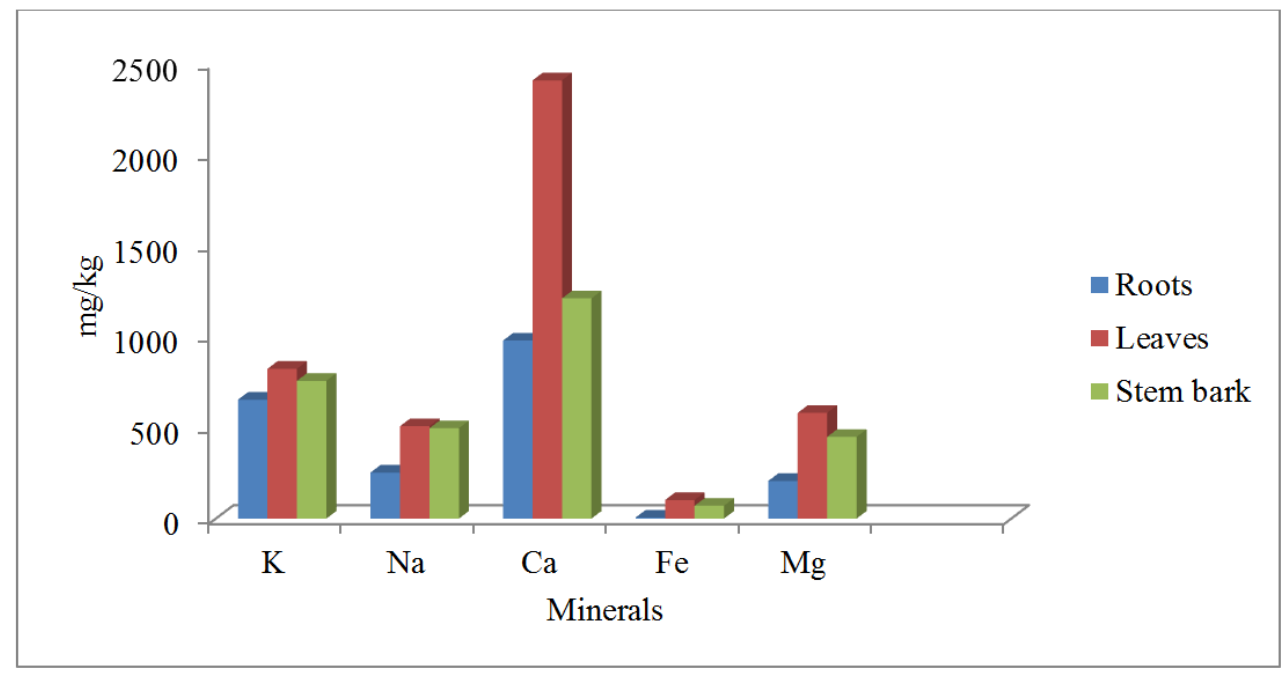

Figure 3. Mineral compositions of the roots, leaves and stem bark of Bobgunnia fistuloides in mg/kg.

The concentration of sodium $(507.24 \mathrm{mg} / \mathrm{kg})$ in the leaves obtained in this study was the highest, followed by the stem bark $(496.13 \mathrm{mg} / \mathrm{kg})$ while lowest was found in the roots $(252.83 \mathrm{mg} / \mathrm{kg})$. The results are higher compared to the concentration of sodium in Tecomella undulate $(91 \mathrm{mg} / \mathrm{kg})$ and Withania coagulans $(125 \mathrm{mg} / \mathrm{kg})$ as reported by Zain et al. [22]. The $\mathrm{Na} / \mathrm{K}$ ratio recorded on the leaves, roots and stem bark of $B$. fistuloides are $0.62,0.4$ and 0.66 respectively. Kalidass and Mahapatra [25] reported that the recommended sodium to potassium ratio for a given diet or plant is 0.6 . In this study, the roots had the lowest $\mathrm{Na} / \mathrm{K}$ ratio while the leaves and stem bark were higher compared to the recommended daily intake. Any medicinal plant or diet higher in potassium and lower in sodium content are more recommendable for hypertensive patients as higher potassium contents lower blood pressure [25]. This makes the root the most efficient and reliable for hypertensive patients compared to the other parts of the plant [6]. The $\mathrm{Na} / \mathrm{K}$ ratio in the roots of $B$. fistuloides can be useful for prevention of high blood pressure [26].
The calcium content $(2405.48 \mathrm{mg} / \mathrm{kg})$ of the leaves was the highest followed by the stem bark $(1208.64 \mathrm{mg} / \mathrm{kg})$ while the least was the root $(977.36 \mathrm{mg} / \mathrm{kg})$. In all the values obtained for calcium content in $B$. fistuloides parts were significantly higher above the calcium content in Ficus capensis leaves $(1.86 \mathrm{mg} / \mathrm{kg})$ and leaves of Ocimum gratissimum (scent leaf) $(0.14 \mathrm{mg} / \mathrm{kg})$ as reported by Achi et al., [27] and Alexander [28]. The recommended daily intake of calcium for both children and adults are in the range of $800-1200 \mathrm{mg}$ [25]. The results obtained in this study indicate that the roots and stem bark and leaves of $B$. fistuloides can contribute to the required daily intake when consumed. In fact, the obtained calcium content of the leaves are above the recommended range. Calcium is necessary for both teeth and bone formation. It also aids blood clotting and cell metabolism [23]. Reports have also shown that calcium has anti-cancer properties and intake of Ca during pregnancy can help prevent pre-eclampsia [25] and [23]. Thus the intake of crude drugs from the parts of $B$. fistuloides could probably improve the health of a cancer 
patient.

The iron content was more abundant in the leaves $(102.07$ $\mathrm{mg} / \mathrm{kg})$ followed by the stem bark $(70.44 \mathrm{mg} / \mathrm{kg})$ while the roots had the lowest $(6.17 \mathrm{mg} / \mathrm{kg})$. The iron content of the leaves obtained in this study is higher than the $98.2 \mathrm{mg} / \mathrm{kg}$ reported for the leaves of Cassia nigricans by Gbekele-Oluwa [25], and the $90.31 \mathrm{mg} / \mathrm{kg}$ reported for the leaves of Ocimum gratissimum by Alexander [28]. The recommended daily intake of iron is $8-18 \mathrm{mg}$ per day [23]. The results obtained in this study show that $B$. fistuloides could be a potential source of iron. The presence of iron in the parts of $B$. fistuloides analyzed, is essential as it would contribute to red blood cell production as well as promote the transport of oxygen to all parts of the body [25].

The magnesium content of the leaves $(580.26 \mathrm{mg} / \mathrm{kg})$ obtained in this study is higher than the values found in the stem bark (448.54 mg/kg) and the root $(206.35 \mathrm{mg} / \mathrm{kg})$. These values are however very high when compared with those obtained in some medicinal plants such as magnesium content in Ocimum gratissimum $(1.71 \mathrm{mg} / \mathrm{kg})$ by Alexander [28] and Cassia nigricans $(93.33 \mathrm{mg} / \mathrm{kg})$ as stated by Gbekele-Oluwa [25]. The values recorded in B. fistuloides were also higher compared to the $\mathrm{Mg}$ content in Senna obtusifolia $(3.0 \mathrm{mg} / \mathrm{kg})$, Cleome gynandra $(0.67 \mathrm{mg} / \mathrm{kg})$ and Lepta hestate $(1.20 \mathrm{mg} / \mathrm{kg})$ as stated by Keta et al., [6]. The recommended daily intake for magnesium is $200-400 \mathrm{mg}$ [23]. Research indicates that an increase in the intake of magnesium serves as a preventive and protective measure against some chronic disease such as cardiac attack, diabetes, hypertension and metabolic syndrome [23]. Magnesium plays a physiological role by acting against excessive calcium in the bone. The results obtained in this study thus reveal that all parts of $B$. fistuloides could be useful in treating cardiovascular diseases, since magnesium toxicity is rare, an excessive intake of $\mathrm{Mg}$ can result to low blood pressure (hypotension), headache and nausea as reported by Guerrero-Romero and Rodríguez-Morán [29].

\section{Conclusion}

Ethno-medicinally, Bobgunnia fistuloides parts (leaves, stem bark and roots) have been used to treat diseases in Nupe communities, Niger State Nigeria. The results of the analysis show that the leaves, stem bark and roots of Bobgunnia fistuloides contain nutrients and mineral elements that are of high nutritional values. The plant parts are rich in calcium, potassium, ash and carbohydrates but with low fat contents. This indicates that $B$. fistuloides could provide the essential minerals and nutrients needed by the body. The analysis also reveals that all the parts have low moisture contents indicating that these plant parts will have long shelf lives as well as low degree of fungal and bacteria attack. From the findings, the nutritional and elemental composition has proven its herbal application for a very large population of the communities who out rightly depend on it for therapeutic purposes. Further research should be carried out to investigate the phytochemical constituent and antibacterial activities of plant parts.

\section{References}

[1] Okeke, C. U., Izundu, A. I. and Uzoechinda, E. (2008). Phytochemical and Proximate Study of Female Pawpaw (Carica papaya L.) Caricaecae. Journal of Science, Engineering and Technology, 15: 8207-8216.

[2] Okeke, C. U. and Elekwa, I. (2006). Proximate and Preliminary Phytochemical Analyses of Avocado Pear gratissima Gaertn (family Lauraceae). Nigerian Journal of Botany, 19: 156-162.

[3] Dutta, A. C. (2003). Botany for Degree Students. 6th Edn., Oxford University Press, New Delhi, India, pp: 301-588.

[4] Oyen, L. P. A. (2012). Bobgunnia fistuloides (Harms) J. H. Kirkbr. \& Wiersema. [Internet] Record from PROTA4U. Lemmens, R. H. M. J., Louppe, D. andOteng-Amoako, A. A. (Editors). PROTA (Plant Resources of Tropical Africa / Ressourcesvégétales de l'Afriquetropicale), Wageningen, Netherlands. http://www.prota4u.org/search. asp

[5] Alfonso, V. A. and Miller, R. B. (2002). Wood Anatomy of the Brazilian Species of Swartzia and Considerations Within the Tribe Swartzieae.. IAWA Journal, 23 (4): 359-390.

[6] Keta, J. N., Obaroh, Singh, I. O. D., Manga, S. S., Keta, M. N., Attah, D. and Aliyu, D. G. (2018). Nutritive and Proximate Analysis of Some Plants Species in Kebbi State, Nigeria. Equity Journal of Science and Technology, 5 (1): 57-66

[7] Okalebo, J. R., Gathua, K. W. and Woomer, P. L. (2002). Laboratory Methods of Soil and Plant Anlaysis: A Working Manual. $2^{\text {nd }}$ edition. TSBF-CIAT and SACRE Africa, Nairobi, Kenya.

[8] Onwuka, G. I. (2005). Food Analysis and Instrumentation; Theory and practice. Naphthalic Prints. Surulere, Lagos, Nigeria. P. 63-113.

[9] AOAC. (2005). Official Methods of Analysis. 18th edn., Washington D.C. Association of Official Analytical Chemists. p. 106.

[10] Akindahunsi, A. A and Salawu, S. O. (2005). Phytochemical screening and nutrient- antinutrient composition of selected tropical green leafy vegetables. African Journal of Biotechnology. 4: 497-501.

[11] Olayiwola, O. A. (2013). Proximate Composition and Vitamin Levels of Seven Medicinal Plants. International Journal of Engineering Science Invention. 2 (5): 47-50.

[12] Ayoola, P. B and Adeyeye, A. (2009). Proximate Analysis and Nutrient Evaluation of Some Nigerian Pawpaw Seeds Varieties. Science Focus, 14 (4): 554-558.

[13] Olayinka, O. A., Owoeye, T. F., Olasehinde, G. I., Akinlabu, D. K., Owolabi, F. E. and Oluwatosin, Y. A. (2016). Characterization, Proximate Composition and Evaluation of Antimicrobial Activity of Seed Oil of Bauhinia tomentosa. Journal of Biological Science. 16 (4): 102-111.

[14] Ayoola, A. A., Yusuf, A. and Oki, D. G. (2016). Phytochemical Screening and Proximate Analysis of Newbouldialaevis and Allium sativum. Nigeria Journal of Animal Science, (1): 242-256.

[15] David, G. O. (2014). Proximate and Phytochemical Analysis of Cajanus cajan (Pigeon Pea) Leaves. Chemical Science Transactions, 3 (3): 1172-1178. 
[16] WHO. (2020). Healthy diet. Geneva: World Health Organization. Retrieved from, https://www.who.int/news-room/fact-sheets/detail/healthy-diet

[17] Hooper, L., Abdelhamid, A., Bunn, D., Brown, T., Summerbell, C. D. and Skeaff, C. M. (2015). Effects of total fat intake on body weight. Cochrane Database System Rev., (8): CD011834.

[18] Antia, B. S., Akpan, E. J., Okon, P. A. and Umoren, I. U. (2006) Nutritive and Anti-Nutritive Evaluation of Sweet Potatoes (Ipomoea batatas) Leaves. Pakistan Journal of Nutrition. 5 (2): 166-168.

[19] Singh, D., Abubakar, A. S. and Keta, J. N. (2010). Proximate Composition of Tribulus terrestris L. Leaves Commonly Found in Some Part of Kebbi State, Nigeria". Journal of Phytological Research, 22 (2): 199-200.

[20] Gonmong, W. F. (2003). Review of Medical Physiology. 12st edition. Mcgraw National Research Council, NRC. (1989). Recommended dietary Allowances. National Academy Press, Washington DC.

[21] Agida, G. O., Forcados, G. E., Usman, Y., Muraina, I., Ottor, M., Samuel, A. L., Usman, A. S., Makoshi, M. S., Atiku, A. A., Gotep, J. G., Ekundayo, G. N., Oladipo, O. O., Mancha, M. D., Ozele, N., Diugwu, J., Makama, S., Akpojosevbe, J., Tondo, B. and Elisha, I. L. (2017). Proximate, Antinutritional and Mineral Composition of Some Pasture Plants Growing in Vom, Nigeria. Researchjournali's Journal of Agriculture, 4 (8): 1-9.

[22] Zain, U., Musa, K. B., Jameel, A. K., Imam, B. B., Riaz, U., Naser, M. A. and Shumaila, N. (2013). Proximate and nutrient analysis of selected medicinal plants of Tank and South Waziristan area of Pakistan. African Journal of Pharmacy and Pharmacology, 7 (5): 179-184.

[23] Mart'inez-Ballesta, M. C., Dominguez-Perles, R., Moreno, D. A., Muries, B., Alcaraz-L'opez, C., Bast'ias, E.,
Garc'ia-Viguera, C. and Carvajal, M. (2010). Minerals in plant food: effect of agricultural practices and rolein human health. Agronomy for Sustainable Development, 30: 295-309.

[24] Jinadasa, B. K. and Jayasinghe, G. D. (2018). Sodium and Potassium in Selected Food Samples from Sri Lankan Market. International Journal of Public Health and Health Systems, 3 (4): 55-58.

[25] Gbekele-Oluwa, R. A. (2013). Proximate and mineral compositions of the leaves and stem bark of Cassia nigricans. International Journal of Medicinal Plants Research, 2 (7): 242-246.

[26] Kalidass, C. and Mahapatra, A. K. (2014). Evaluation of the proximate and phytochemical compositions of an underexploited legume Mucunapruriensvar Utilis (Wall ex Wight) L. H. Bailey. International Food Research Journal, 21 (1): 303-308.

[27] Achi, N. K., Onyeabo, C., Ekeleme-Egedigwe, C. A. and Onyeanula, J. C. (2017). Phytochemical, proximate analysis, vitamin and mineral composition of aqueous extract of Ficus capensis leaves in South Eastern Nigeria. Journal of Applied Pharmaceutical Science, 7 (03): 117-122.

[28] Alexander, P. (2016). Phytochemical Screening and Mineral Composition of the Leaves of Ocimum gratissimum (Scent Leaf). International Journal of Applied Science and Biotechnology, 4 (2): 161-165.

[29] Guerrero-Romero F. and Rodríguez-Morán, M. (2005). Complementary therapies for diabetes: The case for chromium, magnesium, and antioxidants. Arch. Med. Res. 36: 250-257.

[30] Ncube, E., Donald, C., Donatien, P. K. and Kalobwe, M. (2012). Use of a Short Span Field Test to Evaluate Termite Resistance on Eucalyptus grandis and Bobgunnia madagascariensis in a Tropical Environment. Journal of Bioresources, 7 (3): 4098-4108. 